of the American Association and to receive ScIENCE. In order that the work of the association may be carried forward effectively, its membership should be increased to at least ten thousand, and it does not seem to be impossible to accomplish this when we know that the National Geographic Society has by concerted efforts increased its membership to over twenty-five thousand. It would in fact be about accomplished if each member would send one nomination to the permanent secretary. ED.]

QUARTZ AFTER PROCHLORITE AT CRANSTON AND WORCESTER AND COAL PLANTS AT

WORCESTER

To the Editor of Science: During the recent field day of the New England geologists at Providence we were guided by Professor Brown to the graphite mine in the Carboniferous at Cranston. This mine interested me very greatly because of its close resemblance to the coal mine at Worcester, Mass., a resemblance which extended by chance even to the size and shape of the excavation and the dip of the rocks. There was the same greatly mashed and slickensided graphitic slate, the same white and yellow efflorescence of alumina and iron sulphates and a more abundant development of ottrelite in the adjacent schists. Our attention was especially attracted by a white to pale green mineral which filled fissures in the slate with its fine satiny fibers.

This was described as asbestus by Dr. J. W. Webster in the first volume of Silliman's Journal in 1819, and in a note the editor speaks of it as long known. It has been often mentioned since as asbestus, amianthus, or fibrolite. Its action under the microscope was so peculiar that I had it analyzed at Washington by Mr. L. G. Eakins. It proved to be a prochlorite changed in varying degrees to silica. The mean of the analyses roughly recalculated, to omit impurities, was: $\mathrm{SiO}_{2}$, $23.13 ; \mathrm{Al}^{2} \mathrm{O}^{3}, 22.38 ; \mathrm{FeO}, 28.76 ; \mathrm{MgO}, 11.70$; Alk, 1.57; $\mathrm{H}_{2} \mathrm{O}, 12.45$. The fibrous structure seems to be a parting developed in the chlorite by pressure as often happens in the case of muscovite.
The fact that this very peculiar metamorphosis of the carboniferous shales of the Rhode Island basin is exactly repeated at Worcester would be strong evidence that the rocks were of the same age without the coal plants which were found at the Worcester locality some years ago by Mr. J. H. Perry and determined to be Lepidodendron acuminatum by Lesquereux.

This note is written because doubt was expressed at the meeting as to the carboniferous age of the Worcester beds, and an old suggestion was brought up that the fossils were not authentic, that they were perhaps brought there to "salt" the mine. The slabs with fossils were dug up near the mine, one was a foot and a half long and several inches thick; and they were found by two persons at different times and were of exactly the same peculiar graphitic character as the rest of the rock at the mine and equally useless as a fuel, and there is no known locality showing exactly the same characteristics, since even at the Cranston locality the metamorphosis has been a little more severe and no fossils are found there.

The Worcester "coal mine" is the only fossiliferous locality between Providence and Bernardston on the Connecticut, and while there is no doubt that the fossils are coal plants and were found in situ, the common characteristics of the Worcester and Rhode Island beds are so many and so peculiar, and the succession is so similar that no doubt should arise as to their common age.

B. K. EMerson

AMHerst, MASS., November 21, 1907

\section{A SALAMANDER-SNAKE FIGHT}

WHile studying the geology of Buck Peak, twelve miles west of Riddle, Douglas Co., Oregon, last September, I saw a mortal combat that interested me very much because so anomalous. James Storrs, a mountaineer and trapper of California, well acquainted with the habits of wild animals, was with me at the time and remarked that it was "the first ring engagement he had ever seen in which the salamander showed any sand." . In these 